\title{
Determining When NEPA Applies to Nonfederal Activities
}

\author{
C. H. Eccleston \\ B. D. Williamson
}

Date Published

July 1996

To Be Published in

Federal Facilities Environmental Journal

Prepared for the U.S. Department of Energy

Assistant Secretary for Environmental Management

\section{Q8) Westinghouse P.O Box 1970 \\ Hanford Company Richland, Washington}

Management and Operations Contractor for the

U.S. Department of Energy under Contract DE-AC06-87RL10930

Copyright License By acceptance of this article, the publisher and/or recipient acknowledges the

U.S. Government's right to retain a nonexelusive, royalty-free license in and to any copyright covering this paper.

Approved for public release; distribution is unlimited 
LEGAL DISCLAMMER

This report was prepared as an account of work sponsored by an agency of the United States Government. Neither the United States Government nor any agency thereof, nor any of their employees, nor any of their contractors, subcontractors or their employees, makes any warranty, express or implied, or essumes any legal liability or responsibility for the

accuracy, completeness, or any third party's use ar the results of such use of any information, apparatus, product, or process disclosed, or represents that its use would not infringe privately owned rights. Reference herein to any specific commercial product, process, or service by trade name, trademark, manufacturer, or otherwise, does not necessarily constitute or imply its endorsement, recommendation, or favoring by the United States Government or any agency thereof or its contractors or subcontractors. The views and opinions of authors expressed herein do not necessarily state or reflect those of the United States Government or any agency thereot.

This report has been reproduced from the best available copy.

Printed in the United Statea of Amence

DISCLM-2.CHP (1-91) 


\begin{tabular}{|c|c|c|}
\hline $\begin{array}{l}\text { Date Rec cived by IRA } \\
\text { f }\end{array} 396$ & & $\begin{array}{l}\text { NFORMATION RELEASE REQUEST - (Long Form) } \\
\text { (GRAY SHADED AREAS NOT TO BE FILLED IN BY INITIATOR) }\end{array}$ \\
\hline \multicolumn{3}{|r|}{ 1. COMPLETE THIS SECTION FOR ALL DOCUMENTS } \\
\hline \multicolumn{2}{|c|}{ A. Information Category } & B. Document ID Number (include rev., vol., etc.) \\
\hline \multirow{2}{*}{$\begin{array}{l}\text { Speech or Presentation } \\
\square \text { Full Paper } \\
\square \text { Summary } \\
\square \text { Abstract } \\
\square \text { Visual Aid }\end{array}$} & \multirow{2}{*}{$\begin{array}{l}\square \text { Journal Article } \\
\square \text { Multimedia Presentation } \\
\square \text { software }\end{array}$} & WHC-SA-3012-FP, Rew \\
\hline & & \multirow[t]{2}{*}{$\begin{array}{l}\text { C. List attachments (i.e., copyright permission, copyright transfer) } \\
\text { Fu11 paper }\end{array}$} \\
\hline$\square$ other & & \\
\hline
\end{tabular}

D. Document Title

Determining When NEPA Applies to Nonfederal Activities

E. WHC Project or Program

\begin{tabular}{|c|c|}
\hline $\begin{array}{l}\text { F. New or novel (patentable) subject matter? } \\
\text { If "Yes", has disclosure been submitted by WHC? }\end{array}$ & $\begin{array}{l}\text { G. Information received from others in confidence, such as pr } \\
\text { and/or inventions? }\end{array}$ \\
\hline If "Yes", Disclosure No(s): & If "Yos", contact WHC General Counsel. \\
\hline
\end{tabular}

\begin{tabular}{|l|l|l}
\hline H. Copyrights? $[\mathrm{Y}$ No or Yes If "Yes", attach permission. & I. Trademarks? WN No or Yes if "Yes", identity in document.
\end{tabular}
2. COMPLETE THIS SECTION FOR ALL DOCUMENTS REOUIRING SUBMISSION TO OSTI

\begin{tabular}{|l|l|lll}
\hline A. Unclassified Category & UC - Budget \& Reporting Code & B\&R - \\
\hline
\end{tabular}

3. COMPLETE THIS SECTION ONLY FOR A JOURNAL SUBMISSION

A. Title of Journal Federal Facilities Environmental Journal

\begin{tabular}{|c|c|c|c|}
\hline \multicolumn{4}{|c|}{ 4. COMPLETE THIS SECTION ONLY FOR A SPEECH OR PRESENTATION } \\
\hline \multicolumn{2}{|c|}{$\begin{array}{l}\text { A. Title for Conference or Meeting } \\
N / A\end{array}$} & $\begin{array}{l}\text { B. Group or Society Sponsoring } \\
\text { N/A }\end{array}$ & \\
\hline $\begin{array}{l}\text { C. Date(s) of Conference } \\
\text { or Meeting }\end{array}$ & & E. Will material be published in proceedings? & N Na or Yes \\
\hline$N / A$ & $\mathrm{~N} / \mathrm{A}$ & Will material be handed out? & $\square$ No or Yes \\
\hline
\end{tabular}

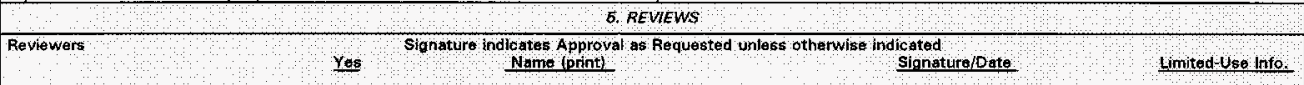

General Counsel

DOERL

Communications

Applied Technology-Export Controlled Information or International Program

other

Other

6. Applied Technology Material Referenced

[ $]_{\text {No }} \square$ res

7. Release Level

[X] Public $\square$ Limited Distribution

8. AuthoriRequestor $6 / 26 / 96$

C. H. Eccleston (Print and Sign)

aresponsible Manager 1

R. H. Engelmann (Print and Sign)
PAULFX. DUNIGAN, dR.
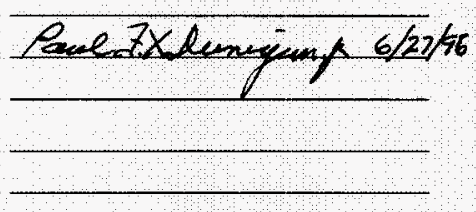

INFORMATION RELEASE ADMINISTRATION APPROVAL

IfA Approval is required before roleabe. Release le contingent upon resolution of mandatory comments. NOTE. This block for IRA use only.

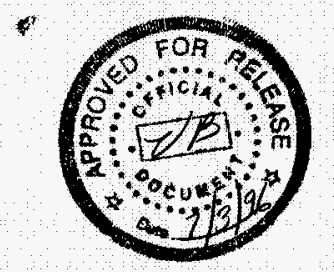

Date Cancelled

Date Disapproved 


\section{WHC-SA-3012-FP, KeT-}

10 LECENDS/NOTICESFIARKINGS (Required by WHC-CM+3-4 or Reviower). Reviewer indicates applicable markings to be offixed or removed.

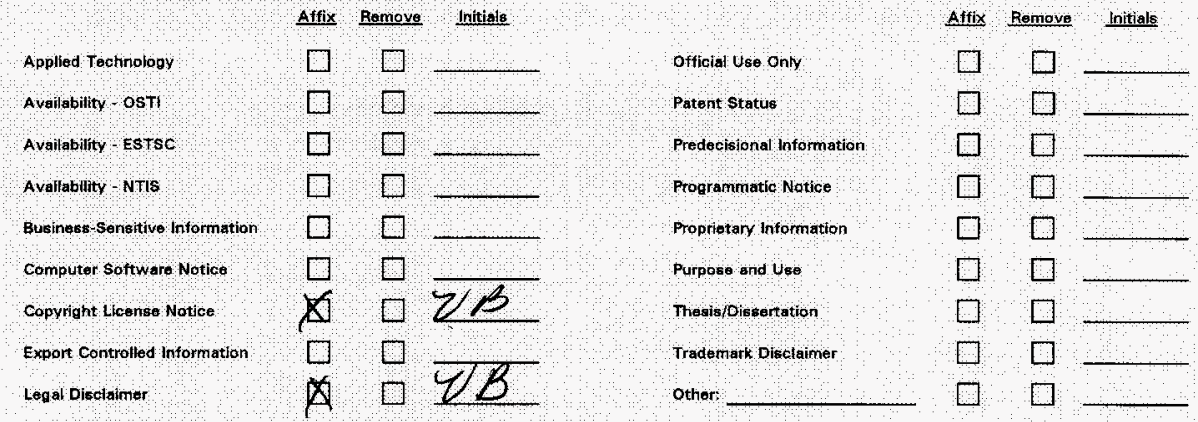

Limited Disclosure

.

11 MANDA TORY COMMENTS thist only mandatory comments here All other comments shall be made on the document and rotumed to the suthord

\begin{tabular}{|c|c|c|c|} 
Reviewer & Resolved by Author/Requestor \\
(Print \& Sign)
\end{tabular}




\title{
DETERMINING WHEN NEPA APPLIES TO ACT]VITIES NOT DIRECTLY CONDUCTED BY FEDERAL AGENCIES
}

\author{
Charles H. Eccleston, Westinghouse Hanford Company \\ Barbara D. Williamson, Westinghouse Hanford Company
}

\begin{abstract}
More than a quarter century after enactment of the National Environmental Policy Act (NEPA), unresolved questions still persist regarding its applicability to state and private actions. This is particularly true when such projects are undertaken to support the needs of a federal agency. Proposed below, is a paradigm for determining when NEPA applies to state or privately conducted, but federally influenced or inspired actions. The paradigm employs a set of five sequential tests for determining if a state or privately conducted action is subject to the requirements of NEPA.
\end{abstract}

\section{INTRODUCTION}

Heralded by its advocates as an effective means for improving government operations, many agencies are championing privatization as a means of meeting their individual charter obligations while operating within constricted budgets. Numerous questions are being raised regarding the applicability of NEPA to state and private projects when such actions are conducted solely or largely in support of federal agency needs. Clearly, the requirements of the National Environmental Policy Act (NEPA) apply to "...major federal actions significantly affecting the quality of the human environment. " 1 But what about nonfedera? projects which are conducted in support of federal agency needs? More specifically, does NEPA apply to state or privately sponsored projects, undertaken in support of federal agency needs? If so, where should the line be drawn between state or private actions subject to NEPA versus those actions which are not?

In examining this question, one should begin by considering the fundamental purpose of NEPA - to bring environmental factors into the federal decisionmaking process. Except by contract specifications or federal approvals, however, a federal agency may have little control over the design and operation of nonfederal facilities. Thus, one is led to ponder what purpose would be served in conducting a NEPA review on actions over which a federal agency cannot exercise some degree of control during the decisionmaking process. This simple supposition provides a starting point for developing a general purpose model. A paradigm will be presented shortly which is specifically designed to answer the following question:

At what point do state or private actions undertaken to support the needs of federal agency become 'federalized', triggering the requirements of NEPA? 
Before continuing into the next section, a word of caution is in order. It must be emphasized that the scope of this paper is limited to the question of determining when NEPA applies to 'nonfederal' actions. This paper does not address the level of NEPA documentation that is appropriate for a particular action, or issues such as when an action is "Major" or its impacts are potentially "significant". These are distinct and separate issues which, as viewed in the context of this paper, are only addressed once a determination has been made that the activity constitutes a "federal action" for the purposes of NEPA. It is important that such issues not be confused with the question of when an action is "federal".

\section{FACTORS THAT MAY FEDERALIZE A PRIVATE OR STATE ACTION}

While it has long been settled that NEPA does not apply to private parties, ${ }^{2}$ various courts have looked at federal actions individually to determine whether the degree of federal involvement was so great as to cause nonfederal projects to become 'federalized' for the purposes of NEPA.

Federal actions generally include those directly undertaken by a federal agency. For the purposes of NEPA, however, state and federal actions which are funded, financed, aided, controlled, permitted, 1icensed, enabled, caused or approved by the federal government may also be subject to NEPA.

The degree of federal involvement, necessary to transform a state or private project from that which is considered nonfederal to one deemed to be federal, for the purposes of NEPA, is somewhat unclear. A review of case law reveals certain instances where the courts have determined that particular circumstances either are or are not subject to NEPA review. Three factors have been used by the courts in determining if federal agency involvement has federalized what would otherwise be considered to be a nonfederal action. Each of these factors are explained more fully in the sections that follow. Specifically, state or privately conducted action may be federalized for the purposes of NEPA if they are:

- Supported by a federal contract, grant, loan, or other financial assistance,

- Enabled through a federal lease, license, permit, or other entitlement,

- Federally caused.

\section{Federal Support by Contract, Grant, Loan or Financial Assistance}

Projects supported by federal "payment for services rendered" can be viewed as requiring NEPA review. " In cases where "federal funding" subjected a state or private project to the requirements of NEPA, the funding was active, as opposed to a passive deferral of payment, and programmatic, in the sense of being provided primarily to further a policy goal of the funding agency. ${ }^{5}$ Normally, a substantial amount of federal funding is necessary to trigger a NEPA review. 


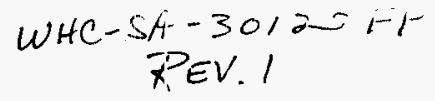

Some nonfederal actions, deriving their finances from federal general revenue funds are considered to be federal if a federal agency governs how the funds are used. As with "federal payment for services rendered", NEPA is required when massive federal financial assistance has been given to the state or private project. ${ }^{6}$ Accordingly, the federal government becomes accountable under NEPA for its actions.

Conversely, nonfederal actions were not federalized when indirect funding "seemed marginal at most" and where federal officials had no decisionmaking role. ${ }^{8}$ For example, federal participation in a California beetle eradication project was not sufficient to trigger NEPA compliance. Insufficient federal action existed where three federal officials sat on an eight member board which made recommendations to the state on eradicating a Japanese beetle pest infestation. The court reasoned that the eradication project was not federally funded because the traveling expenses of the participating federal officials were paid by the state and the eradication project was a state project. The court considered the fact that the salaries of the participating federal officials for the duration of the board meetings were not reimbursed by the state and still supported this ruling.

\section{Federal Control}

Federal control over a state or private project may be sufficient to federalize such actions. A federal action, such as, the federal approval of a lease, license, permit, certificate or other entitlement which enables a private or state action to take place may be subject to NEPA. In such circumstances, overt federal agency action in furtherance of the nonfederal project is necessary before a federal action can be found. ${ }^{10}$ For example, the Pueblo Indians leased restricted Indian lands to a development company and the Bureau of Land Management (BLM) approved the lease. "11 Emphasizing Congress's concern for environmental protection, the court held that BLM approval constituted major federal action even though the federal government neither initiated the lease nor participated in it financially.

\section{Enablement by Lease, Permit, License or Entitlement}

Federal enablement entails federal agency decisions which must take place prior to actions being taken by nonfederal entities. In cases involving federal enablement, the federal agency decision was required by statute and was a legal precondition authorizing another party to proceed with an action affecting the environment. When an agency has discretion in its enabling decision to consider environmental consequences and that decision forms the legal predicate for another's impact on the environment, preparation of NEPA documentation is warranted because the agency has substantially contributed to the environmental impact. ${ }^{13}$ The Council on Environmental Quality's (CEQ) regulations reinforce the concept that enablement involves executing a required federal action that enables a private party to pursue an action. The definition of "major federal action" includes the granting of permits or other regulatory decisions as well as federal and federally assisted activities. Noticeably omitted from this definition are federal actions that amount to less than a legal precondition. ${ }^{14}$ 


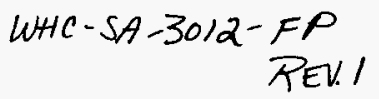

The enablement concept is demonstrated by a case involving the Department of Agriculture which was required to prepare an Environmental Impact Statement (EIS) because of its approval of logging operations by a private company. Evidence demonstrated that the federal agency had a responsibility greater than a ministerial act of approval.' It had also extended logging contracts, modified contracts, and had a financial interest in the lumber acquired. The actions of the federal agency enabled the logging operations in the area to be undertaken, but most significantly, the federal agency was legally obligated by contract to give its approval to a project before that project could be undertaken.

In other cases, federal approval of a private party's project, where that approval was not required for the project to go forward, did not constitute a federal action. ${ }^{16}$ However, a nonfederal entity could create a federal action if it consented to federal regulation or granted the ability to control the outcome of the proposed project to a federal agency. ${ }^{17}$ A distinguishing characteristic of federal involvement is the ability to influence or control the outcome of a nonfederal project in some material respect.

\section{Continuing Agency Involvement that is Terminated or Modified}

Some courts will also review whether there is "continuing" agency involvement in a challenged project such that termination or modification of the agency involvement would terminate or significantly impact the project. Since NEPA requires federal agencies, not states or private parties, to consider the environmental impacts of their proposed actions, nonfederal actions must sufficiently involve federal actions.

\section{Causation}

A legal principal, referred to as "causation" is an additional factor that has sometimes been used by the courts in determining that a nonfederal action has become federalized for the purposes of NEPA. A nonfederal action may be federalized, if the nonfederal action would not take place, were it not for specific actions undertaken by a federal agency. That is, "but for" the federal action, the nonfederal action would not occur. These "but for" actions, by themselves, however, do not necessarily trigger the requirements of NEPA. Rather, the federal action must also be substantially "interrelated" to the otherwise nonfederal action. ${ }^{19}$

\footnotetext{
1 For the purposes of NEPA, a ministerial act can be viewed as an action that an agency must undertake at the direction of some authority such as Congress, and over which the agency has no discretion as to whether it will take place.
} 


\section{TECHNICAL BASIS FOR DEVELOPING A DEFENSIBLE AND GENERAL-PURPOSE MODEL}

Exhibit l summarizes the case law criteria, which has been discussed earlier for determining when a nonfederal project has become federalized for the purposes of NEPA. These criteria provide the basis for the general-purpose model presented in Exhibit 2.

Exhibit 1. Criteria for Determining When Activities Conducted by NonFederal Entities May Become Federalized for the Purposes of NEPA.

- Is the federal action substantially "interrelated" with a nonfederal action to such an extent that "but for" the federal action, the nonfederal action would not take place?

- Is there "continuing" federal involvement in a nonfederal action to such an extent that termination or modification of this involvement would terminate or significantly impact the nonfederal project?

- Would the nonfederal action involve a substantial degree of federal control?

- Would the nonfederal action involve a substantial degree of financial support by way of a federal contract, grant, loan, or other financial assistance?

- Would the nonfederal action be enabled through a federal lease, license, permit, or other entitlement?

\section{A GENERAL-PURPOSE MODEL FOR DETERMINING WHEN NONFEDERAL PROJECTS ARE SUBJECT TO NEPA}

The logic diagram presented in Exhibit 2 is based on the criteria established in Exhibit 1. The model is specifically designed to provide decisionmakers with a rigorous and systematic procedure that will assist an agency in determining if a nonfederal action has become federalized, thus triggering the requirements of NEPA. The model can be applied to actions that take place both within and outside the boundaries of a federally controlled area or facility. Each of the tests presented in Exhibit 2, summarizes the corresponding criteria that are more fully described in Exhibit 1 and earlier in this paper.

The model should be implemented on a case-by-case basis. Technical aspects of the case law summarized earlier in this paper should be considered in responding to each of the tests. Where appropriate, this model can be modified to accommodate changing criteria or special circumstances. 
THERE IS FEDERAL ACTION, SIGNIFICANTLY, "INTERRELATED" TO THE 'NONFEDERAL' ACTION, SUCH THAT:

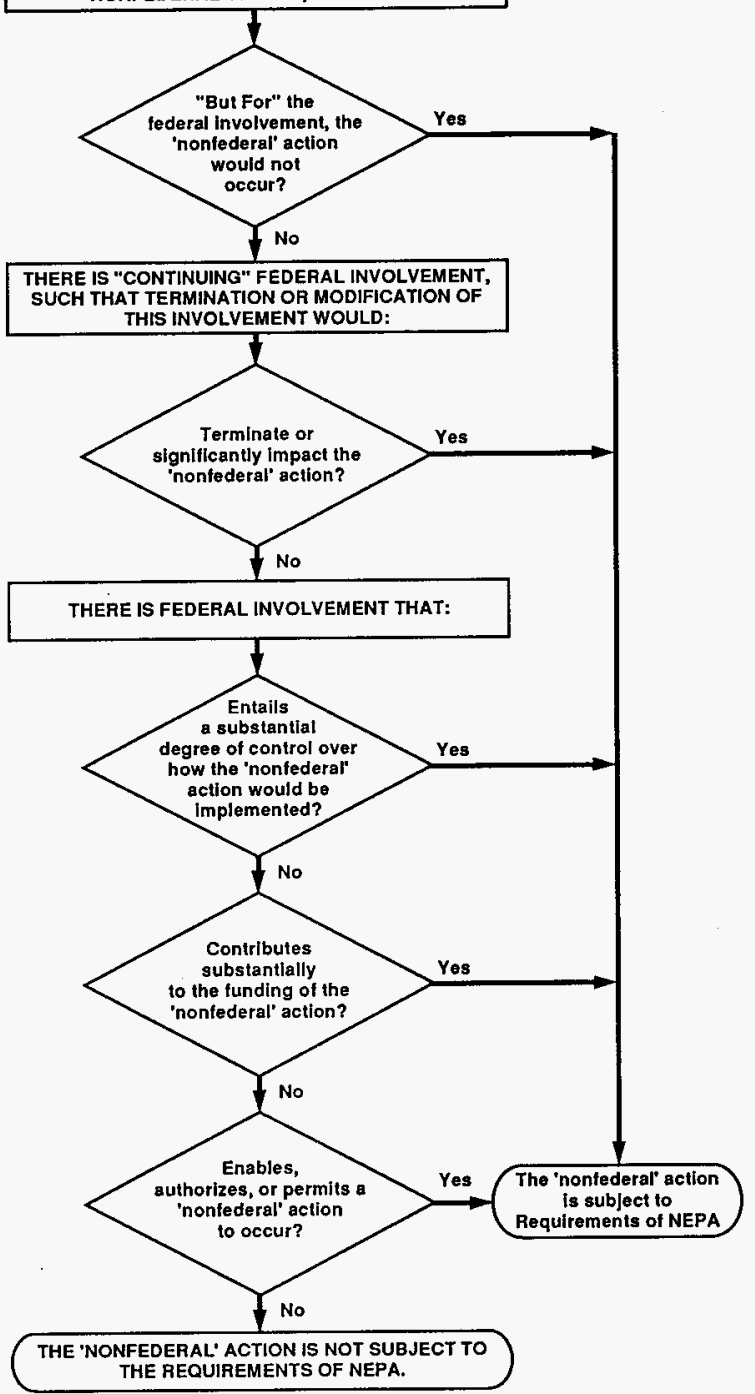

Exhibit 1. Model for determining when NEPA applies to nonfederal actions. 
Professional judgment is exercised in cases where the answer t.o any test is not clearly obvious.

While the model is intended to be used as a general-purpose decisionmaking tool, it cannot cover every conceivable condition. Exceptions may arise that cannot be appropriately addressed by the model. In some instances, the particular facts and circumstances may necessitate consideration of other factors. Legal counsel should be consulted before a final determination is made. A description of how the model is to be implemented is portrayed in the following sections.

\section{USING THE MODEL TO MAKE DETERMINATIONS}

Application of the model begins by reviewing the relationship between the nonfederal action and the federal action. One begins at the top of Exhibit 2 by answering the first question, i.e., "Is the federal action significantly interrelated to the federal action such that 'but for" the federal action, the nonfederal action would not occur?" If the response is "no", the decisionmaker continues down through the remaining tests. A "no" answer to all of the tests supports a decision that the nonfederal action is not subject to the requirements of NEPA. A "yes" answer to any single test is sufficient to support a decision that the nonfederal action is subject to the requirements of NEPA.

\section{ADVANTAGES AND LIMITATIONS OF THE MODEL}

Currently, many agencies are faced with the problem of having to determining when state and privately conducted activities are subject to the requirements of NEPA. Lacking a general-purpose methodology, relevant factors may be overlooked and determinations may be made inconsistently. The model shown in Exhibit 2, provides a general-purpose tool that can be applied, in making such determinations, to a broad array of state and privately conducted activities. The model does not promote any level of decisionmaking beyond that already exercised on a routine basis. Quite the contrary. The mode 1 provides decisionmakers with a rigorous, systematic and defensible approach for making such determinations.

As witnessed earlier, implementation of this model should be restricted to the question of determining whether the requirements of NEPA apply to actions that might otherwise be considered nonfederal; neither is the model designed to be used in addressing other NEPA compliance issues such as determining the level or amount of NEPA documentation that is appropriate for the action.

Undeniably, this model does not eliminate the subjectivity inherent in such determinations. However, the model provides a valuable tool for substantially reducing the vast number of factors that decisionmakers, lacking such a model, may be inundated with. In implementing this model, decisionmakers and critics alike are expected to provide specific and rational arguments justifying why a specific response is or is not warranted for each of the tests. 


\section{ADDITIONAL FACTORS THAT MAY BE CONSIDERED}

While the procedure presented in Exhibit 2 is based in case 1aw, an agency might consider expanding the model to include more specific factors that are intrinsically related to the tests shown in the model. For example the model might be revised to include additional or more detailed factors such as those presented in Exhibit 3.

Consider, for instance, the last item in Exhibit 3, an activity taking place within the federal enclave. An activity conducted within the boundaries of a federally controlled facility or area provides a particularly objective factor that may be decisive in determining the applicability of NEPA. Privatization actions proposed to take place within the boundaries of a federally controlled facility are almost certainly subject to the requirements of NEPA. This conclusion draws from the fact that privatization actions taking place on a federally controlled site would undoubtably involve a lease for use of the federal land and in circumstances where a service will be provided, a contract specifying performance of such services. Moreover, the lease and the contract would almost unquestionably subject the private entity to certain federal regulations, rules, orders and other federal control.

Exhibit 3. Additional Factors that Might be Considered in Determining When Activities Conducted by NonFederal entities become Federalized Triggering NEPA Consideration.

- Is there direct federal control in determining the specific alternatives to the proposed action?

- Is there direct federal control or supervision over a substantial portion of the nonfederal activity?

- Is there substantial agency involvement in design, construction or operation of the nonfederal activity?

- Does the agency have authority to prevent the action from taking place?

- Has the agency actively solicited the nonfederal action?

- Does a statute or regulation limit the federal action with respect to the nonfederal action?

- Would the action take place on federally owned or managed property? 


\section{$w H C-54-=01 \alpha-i-1-$ \\ REV.'}

\section{DOES THE MODEL WORK?}

Described below are two examples involving onsite and offsite projects conducted by the private sector. The examples illustrate how the model can be used in making determinations regarding the applicability of NEPA.

\section{PRIVATE ACTION OCCURRING ON FEDERALLY CONTROLLED PROPERTY}

A federal agency needs to treat hazardous waste to meet land disposal restrictions. In 1 ieu of constructing and operating a hazardous waste treatment facility, the agency proposes to purchase those services from a private party. Specifically, the agency proposes to lease a parcel of 1 and within the federal enclave to a private entity who would then finance, construct, and operate the hazardous waste treatment facility to process the agency's hazardous waste. The agency would have no involvement in the actual waste processing operation. The agency solicits proposals from private entities to supply such services. Is this privatization action subject to a NEPA analysis?

Begin by determining if the federal action is interrelated with the nonfederal action to such an extent that the nonfederal project would not take place "but for" actions undertaken by the federal agency. Here, the facility would not be built were it not for the request and guarantee by the federal agency to purchase the services of the waste treatment services. The answer to the first test is, therefore, "yes" and provides a sufficient basis for concluding that the action is subject to NEPA. For the purposes of illustration, however, let us continue evaluating the remaining tests shown in Exhibit 2 .

Continuing on to the second test, we next ask whether a termination or modification in the governments action would terminate or substantially effect the nonfederal action. This question first involves determining if there is "continuing" federal involvement? So long as the federal government supplies hazardous waste to a private treatment facility there is federal involvement by way of payment for services rendered. Depending on the lease and contract provisions, there may also be ongoing federal oversight of the hazardous waste treatment operation. Now that the first part of this question has been answered we turn our attention to addressing the tests in general. In awarding a services contract, the federal government would be supporting the hazardous waste facility by supplying not only the waste to be treated, but also, the dollars for doing so. Halting or changing the volume of government waste to be treated could significantly effect a facility reliant on government wastes for continued financial viability. As in the case above, a review of this tests leads to the conclusion that the action is subject to NEPA.

The final three tests involve the question of whether the nonfederal project is federally controlled, receives federal funding, or involves federal approval? To an extent, the response is "yes", since the federal government would undoubtedly issue a lease with conditions, i.e., proper operation of the hazardous waste treatment facility, liability clauses, and measures to prevent contaminating the government 1 and. The federal government would also approve or set the conditions for approving the hazardous waste services contract 


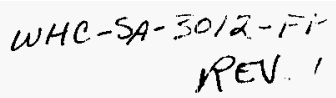

which may likewise give the government some control over the operation of the facility.

This leaves the question of whether the nonfederal project is substantially financed with federal funds. The response to this question is also "yes", since the federal government is the only entity which is purchasing the service from this company. Review of the final three tests also leads to the conclusion that the action is subject to NEPA.

\section{PRIVATE ACTION OCCURRING ON PRIVATE PROPERTY}

Now, consider a second example. Suppose a federal agency has a need for additional waste water treatment and solicits proposals from private entities to supply such services. Further, suppose a private company responding to the request for proposal, already owns the land and treatment plant and it plans to renovate the plant regardless of whether it is selected to provide the services for the federal agency. The quantity of federal waste water processing would be only a small fraction of the total volume of waste water that the entity will be processing. Is the nonfederal action (renovating the piant) subject to NEPA?

Begin by asking the following: Would the nonfederal action be significantly interrelated to federal actions such that it would not take place, "but for" actions undertaken by the federal agency? The answer to the test is "No" since the facility renovation would take place regardless of whether the federal agency purchases waste water treatment services.

Is there continuing federal involvement? There is federal involvement to pay for services rendered. However, the nonfederal entity is not significantly reliant on such services to the point where modification or termination of the contract would significantly affect the action. Consequently, this test has not been triggered.

As indicated, the company planned to renovate the plant regardless of the federal agency's utilization of its services. The federal agency purchasing the waste treatment services will not approve the renovation plan, nor is there any significant degree of control by the agency over this activity. Likewise, this test does not trigger NEPA.

The federal agency is not supplying direct federal financial assistance for the plant renovation nor will it be purchasing a substantial amount of the entity's total processing services. Even though the federal agency will be paying for services rendered, it is safe to conclude that the plant is not significantly reliant on the federal government's support because the renovation will go forward whether or not a services contract is awarded to the nonfederal entity. This test does not trigger NEPA.

There are no federal permits, 1 icenses, certificates or entitlements requiring the federal agency's approval. The federal agency would, of course, approve the service contract. Acceptance controls may also be imposed by the nonfederal entity upon the federal agency concerning the waste streams but probably not vice versa since the nonfederal entity will not be returning the waste water or residual waste constituents to the federal agency. Federal 


\title{
$W H C-S H-S C / \alpha-F-$ \\ REV. !
}

control in this test seems minimal. The final test does not appear to trigger a NEPA review.

None of the tests appear to be triggered. Based on this review, it is reasonable to conclude that the action is not subject to NEPA.

\section{SUMMARY}

The paradigm, described above, describes a general-purpose tool for determining when nonfederal activities are subject to the requirements of NEPA. A set of five distinct tests, based on case $1 \mathrm{aw}$, are used for reaching a determination. The model does not promote any degree of decisionmaking beyond the level already exercised in making such determinations. Instead, the model provides decisionmakers with a rigorous, systematic, and defensible approach for making such determinations.

This model should be implemented on a case-by-case basis. The model does not totally eliminate the subjectivity inherent in making NEPA determinations, but provides a valuable tool for substantially reducing such subjectivity. This is because the universe of potential considerations that are used to justify a particular position are essentially reduced to a set of narrowly defined tests.

Decisionmakers and critics are expected to provide specific and rational arguments, justifying a NEPA determination, via each test addressed in the model. Clearly, professional judgment must be exercised in instances where the answer to any test is not obvious. Occasionally, exceptions may arise that cannot be appropriately addressed with this model. While the model is designed to be used as a general-purpose tool, other factors may also be considered before reaching a final determination. Legal counsel should be consulted before a final determination is made. Properly implemented, this procedure promotes a consistent and more objective approach for making such determinations.

\section{REFERENCES}

\author{
42. U.S.C. $\$ 4332(2)(C)$
}

United States v. Stoeco Homes, 498 F.2d 597 (3rd Cir., 1974); cert. den. 420 U.S. 927 (1975), 95 S. Ct. 1124 .

National Association for the Advancement of Colored People (NAACP) V. The Medical Center, 584 F.2d 619, at 630 (3rd Cir. 1978).

4. See, National Association for the Advancement of Colored People (NAACP) v. the Wilmington Medical Center, Inc., 426 F. Supp. 919, (1977)(Where a large portion of the nonfederal renovation project would be borne by the federal government through payment for services provided); later proceeding 453 F. Supp 280 (1978); later proceeding on discrimination claim 453 F. Supp. 330 (1978); and remanded 599 F. 2d 1247 (3rd Cir. 1979), on remand 491 F. Supp. 290, (1980); aff'd 
657 F. 2d 1322, (1981) and later proceeding on attorney fees 530 F. Supp. 1018 (1981), rev'd on other grounds 689 F.2d 1161 (3rd Cir., (1982); reh. den. 693 F.2d 22 (3rd Cir., (1982); cert. den. 460 U.S. 1052 , (1983), 103 S. Ct. 1499, (1983).

See, e.g., Landmark West v. US Postal Service, 840 F. Supp. 994 (1993).

See, e.g., City of Davis v. Coleman, 521 F.2d 661 (federal financial participation in the construction of a highway system); Monroe County $v$. Volpe, 472 F.2d 693 (2nd Cir. 1972) (federal financial assistance of $60 \%$ of proposed highway cost of which the viaduct section alone would exceed $\$ 14$ milion dollars); Scherr v. Volpe, 466 F.2d 1027 (7th Cir. 1972) (federal financial aid for the extensive construction of two-lane conventional highway into a four-lane freeway).

NAACP at 631 .

8. See, Sierra Club v. Hodel, 848 F.2d at 1089 (quoting W. Rogers, Environmental Law, at page 763 (1977); and Almond Hill school v. US Dept. of Aqriculture, 768 F.2d 1030, 8.1039 (9th Cir. 1985).

Almond Hill School v. US Dept. of Aqriculture, 768 F.2d 1030, (9th Cir. 1985).

See, Defenders of Wildlife v. Andrus, 627 F.2d 1238, at 1245 (D.C. Cir. $1980)$ and NAACP at 629 .

Davis v. Morton, 469 F.2d 593, (10th Cir. 1972).

See Goos v. Interstate Commerce Commission, 911 F.2d 1283, 1269 (8th Ar. 1990 ), (where the Eighth Circuit reinforced its threshold applicability decisions from Rinqsred $v$. Duluth, 828 F.2d 1305 (8th Cir. 1987). See also, Sierra Club v. Hode1, 675 F. Supp. 594, 612 (1987).

NAACP, 584 F.2d 619, at 633 (3rd Cir. 1978).

40 C.F.R. 1508.18 .

In Minnesota Public Interest Research Group V. Butz, 498 F.2d 1413, (8th Cir. 1974).

See, NJ Dept. of Env'l Protection v. Lond Island, 30 F.3d 403 (3rd Cir. 1994 ) (where a non-federal party voluntarily informs a federal agency of its intended activities to ensure that they will comply with law and regulation, and to facilitate the agency's monitoring of the activities for safety purposes, the agency's review of the plan does not constitute a major federal action); See also, e.g., National Forest Preservation Group V. Butz, 485 F.2d 408 (9th Cir. 1973) (federal government exchanged certain park lands for those owned by a private enterprise to exercise impact on the lands); Davis v. Morton, 469 F.2d 593 (10th Cir. 1972) (government agency required by law to approve a lease on Indian property in order to have a valid lease was ordered to fila an EIS because without its approval the lease would be invalid as a matter of law); Lathan v. Volpe, 455 F.2d 1111 (9th Cir. 1971) (DOT ordered to file an EIS where federal approval of highway construction plans was legally required in order to qualify for federal funding).

See, Environmental Rights Coalition, Inc. V. Austin, 780 F. Supp. 584 (1991). 
18. See, Gettysburg Battlefield Preservation Ass'n v. Gettysburg College, 799 F. Supp. 1571, 1577 (1992) (quoting

Environmental Rights Coalition, Inc. V. Austin, 780 F. Supp. 584 (1991) where the court resolved that without the requisite involvement in a project by a federal agency, the project simply does not involve a major federal action (necessary to trigger NEPA) no matter how much the project may impact the environment).

See Landmark West v. US Postal Service, 840 F. Supp. 994 (1993). 